\title{
Lithological modelling based on shear wave velocity using horizontal to vertical spectral ratio (HVSR) inversion of ellipticity curve method to mitigate landslide hazards at the main road Of Samigaluh District, Kulon Progo Regency, Yogyakarta
}

\author{
Skolastika Novita Widyadarsana $^{1}$, and Eddy Hartantyo ${ }^{1 *}$ \\ ${ }^{1}$ Department of Physics, Universitas Gadjah Mada, Yogyakarta 55281, Indonesia
}

\begin{abstract}
Many landslides occur in Samigaluh District, Kulon Progo Regency, Yogyakarta, Indonesia. However, no research discusses landslides that often occur on the main road connecting the city of Yogyakarta and various tourist resorts in Samigaluh. This study aims at determining the soil vulnerability and lithology model at that main road as a contribution to landslide mitigation planning. This lithology model is based on shear wave velocity (Vs) and layer thickness derived by microtremor datasets. The data were processed by the inversion of the Horizontal to Vertical Spectral Ratio (HVSR) technique of the ellipticity curve method. The result of the study shows that the first layer is associated with topsoil which has Vs of $263 \mathrm{~m} / \mathrm{s}$, the second layer is clay which has Vs of $607 \mathrm{~m} / \mathrm{s}$, the third layer consists of clay, breccia, and pumice which has Vs of $1119 \mathrm{~m} / \mathrm{s}$, and the fourth layer is andesite bedrock which has Vs of $1721 \mathrm{~m} / \mathrm{s}$. Andesite is impermeable to water and can become a slip field for landslides. Clay, breccias, and pumice can absorb water so that their weight increases when it rains. When they are on an impermeable rock on a certain slope, a landslide occurs.
\end{abstract}

\section{Introduction}

Samigaluh District, Kulon Progo Regency, Yogyakarta, Indonesia is geologically a part of the Kulon Progo Mountains which is in the form of a dome with a flat top and steep surroundings nicknamed the "Oblong Dome". This district has two rock formations, namely the Kebo Butak Formation and the Jonggrangan Formation. The Kebo Butak Formation has a lithology of volcanic breccia with fragments of andesite, lapilli tuff, tuff, lapilli breccia, insertion of andesite lava flows, agglomerates, and volcanic sandstone. Meanwhile, the Jonggrangan Formation generally consists of conglomerate, tuffaceous marl, coral limestone, and calcareous sandstone with mollusc content and claystone with lignite insertion.

The topography of this area is dominated by hills with steep slopes make Samigaluh District has a high potential for landslide hazard. The steeper the slope and the higher the runoff rate, the value of soil stability will be smaller. A large number of residents and natural tourist resorts which are located around the main road of the Samigaluh District makes this main road a vital infrastructure that functions to connect Yogyakarta and tourist resorts in Samigaluh District. The slope of the Samigaluh District is dominated by a slope of $25-45 \%$ (steep) which is marked in yellow and a slope of $>45 \%$ (very steep) which is marked in red
[1]. The slope map of Samigaluh District is shown in Fig. 1.

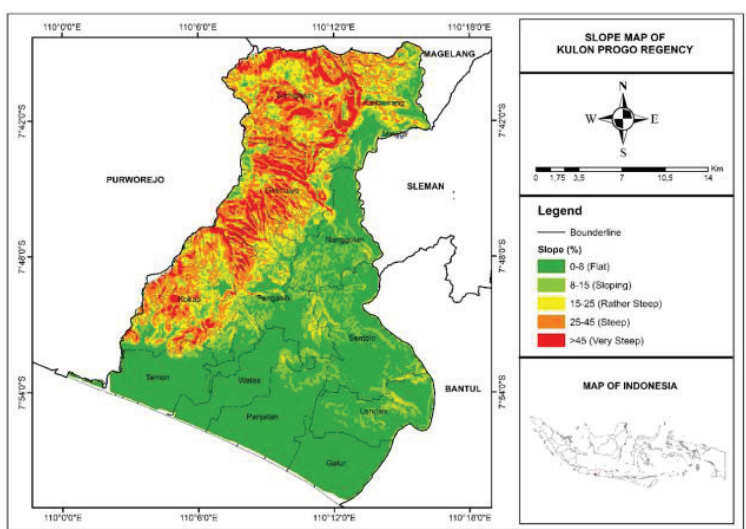

Fig. 1. Slope map of Kulon Progo Regency [2].

The type of landslide that occurs around the main road in Samigaluh District is the flow of debris because the landslide occurs due to high rainfall, which is then able to erode and move soil or soft rock on steep slopes [3].

According to [4], there were 26 landslides (54.17\% of the total landslides in Kulon Progo Regency) occurred on the Samigaluh District main road. The recent landslide that occurred on the Samigaluh District main road are shown in Fig. 2(a) and (b).

*Corresponding author: hartantyo@ugm.ac.id 


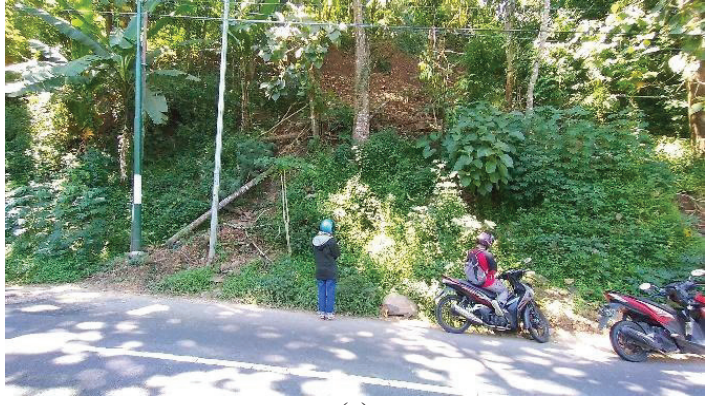

(a)

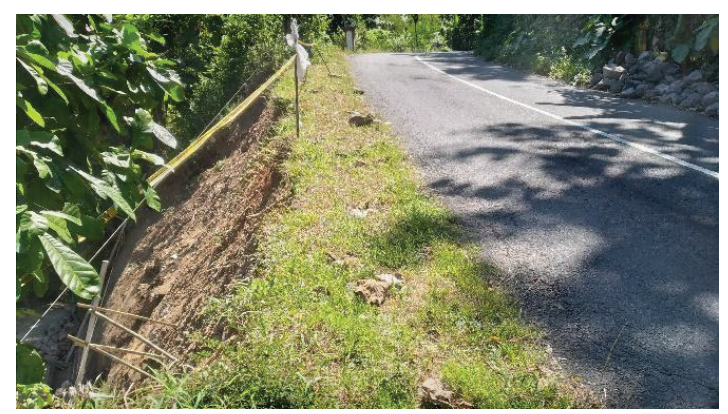

(b)

Fig. 2. The landslide occurred on the main road from the east of Samigaluh District: (a) on the right side and (b) on the left side.

Many landslides occur in Samigaluh District, but no research discusses landslides on the main road. There are many natural tourist resorts around the main road in Samigaluh District. The number of natural tourist resorts is one of the potential income in this district. Moreover, the Kulon Progo Regional Government has also designated Samigaluh District to be one of the Integrated Menoreh Agrotourism Rural Areas based on the Kulon Progo Regent's Decree Number 367/C/2016 [5]. So it is important to know the potential for landslides because the main road in Samigaluh District is a vital infrastructure to support transportation, economic development and ease of community mobility, goods and services. Research conducted by [6-7] shows the dominant frequency and amplification values in Samigaluh District. While research [8] shows the value of shear wave velocity and lithology located in Samigaluh District.

To mitigate the landslide hazard, we mapped the soil vulnerability and lithology based on shear wave velocity (Vs) and layer thickness derived by microtremor datasets. Microtremor in soil structure studies is used to determine subsurface conditions [89]. This method was chosen because the equipment used is relatively simple, low cost, does not require a lot of energy [10] and low cost [11]. Lithology plays an important role in the occurrence of landslides because it affects the strength and permeability properties of the bedrock associated with the slope [12].

\section{Method}

\subsection{HVSR Inversion of Ellipticity Curve Method}

The inversion process is a data matching process to find parameters that produce the best model with a small misfit value (minimum misfit) [13]. The ellipticity curve is one of the modelling methods that can be used to invert the HVSR curve. The principle of this method is to separate Rayleigh waves from other types of waves by combining the signal window from the microtremor data. Then calculate the energy of the sum of the vertical and horizontal signals from the signal window. This energy is used to estimate the ellipticity of Rayleigh waves. Rayleigh wave ellipticity as a function of frequency is related to the underground structure, that is the profile of shear wave velocity and sediment thickness [14]. Furthermore, the value of the shear wave velocity (Vs) will be used to estimate the subsurface lithology in the study area. Subsurface lithology modelling was obtained using Geopsy software.

\subsection{Data acquisition}

Several measurement requirements, as well as technical site selection and microtremor data collection techniques, are set by the SESAME European Research Project [15]. The research area is located in Samigaluh District, Kulon Progo Regency, Yogyakarta Special Region. The measurement area covers an area of 3000 x 4650 meters with a measurement distance of 450 meters and is carried out at 31 points. Data collection at each point was carried out for 40 to 50 minutes with a sampling frequency of $100 \mathrm{~Hz}$. The selection of this study area is based on the distribution of tourism in the research area. The study area is shown in Fig. 3.

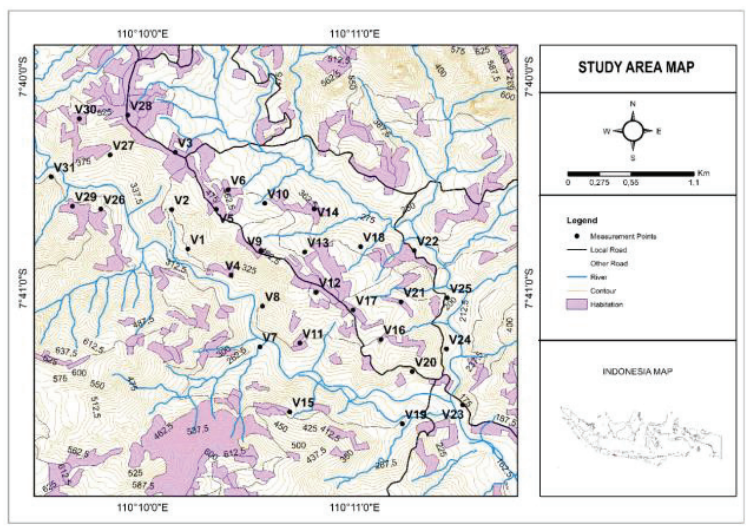

Fig. 3. Study area map [16].

\subsection{Data analysis}

The microtremor data is then processed with Horizontal to Vertical Spectral Ratio (HVSR) in Geopsy software which produces an HVSR curve. The HVSR curve as input data is inverted using the Dinver menu in the Geopsy software. Parameters in the form 
of $\mathrm{P}$ wave velocity (Vp), $\mathrm{S}$ wave velocity (Vs), and density are used as limits to obtain a model that approximates the actual subsurface structure. The parameters in this study refer to previous studies [8, 17-19]. Based on previous research, researchers made parameters in the research area which can be seen in Table 1.

Table 1. Parameters of study area.

\begin{tabular}{cccc}
\hline Layer & $\mathrm{Vp}(\mathrm{m} / \mathrm{s})$ & $\mathrm{Vs}(\mathrm{m} / \mathrm{s})$ & $\rho\left(\mathrm{kg} / \mathrm{m}^{3}\right)$ \\
\hline 1 & $500-1500$ & $100-1200$ & $500-1500$ \\
2 & $800-2000$ & $120-1200$ & $1000-2000$ \\
3 & $1000-2500$ & $150-1500$ & $1200-2500$ \\
4 & $1200-3500$ & $200-2000$ & $1500-3500$ \\
\hline
\end{tabular}

\section{Results and Discussion}

The inversion of the HVSR curve produces ellipticity curves and ground profiles. The ellipticity curve shows the fit between the model created and the HVSR curve (misfit). The black colour on the ellipticity curve shows the HVSR curve, while the red colour shows the smallest displacement of the inversion result. Colours other than red and black on the ellipticity curve show the modelling curve with various misfit values. An example of an ellipticity curve display can be seen in Fig. 4.

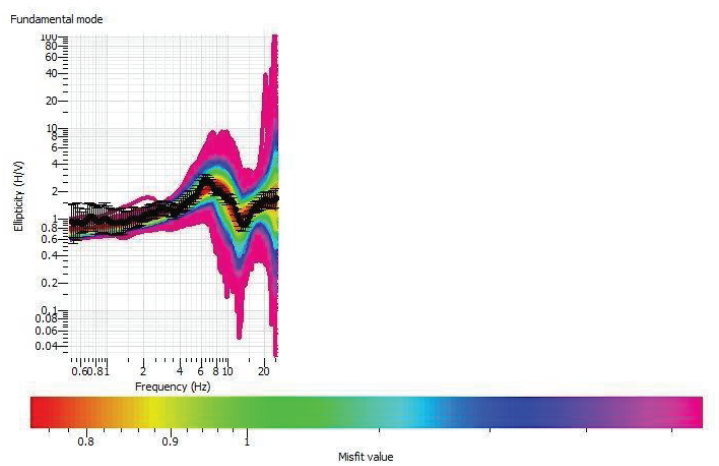

Fig. 4. Ellipticity curve of V4 site.

Ground profiles are modelling results that show the values of $\mathrm{P}$ wave velocity (Vp), S wave velocity (Vs), and density with varying depths. The black colour on the ground profiles display shows the smallest misfit of the inversion result. Colours other than black on the ground profiles show the modelling results with various misfit values. An example of the display of ground profiles can be seen in Fig. 5.

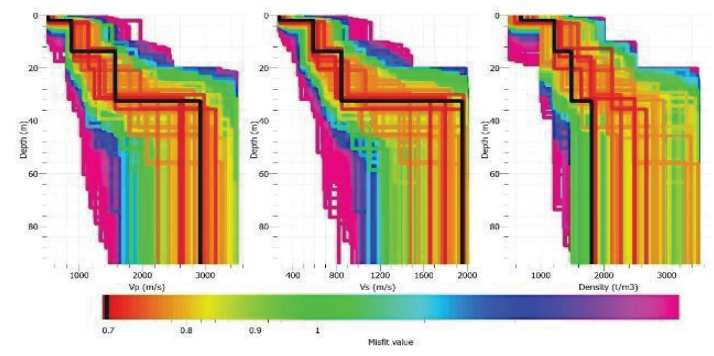

Fig. 5. Ground profiles of V4 site.
Based on the results of the inversion of the ellipticity curve, the average shear wave velocity value in the first layer is $263 \mathrm{~m} / \mathrm{s}$, the second layer is 607 $\mathrm{m} / \mathrm{s}$, the third layer is 1119 and the fourth layer is 1721 $\mathrm{m} / \mathrm{s}$. The modelling of the shear wave velocity can be seen in Fig. 6.

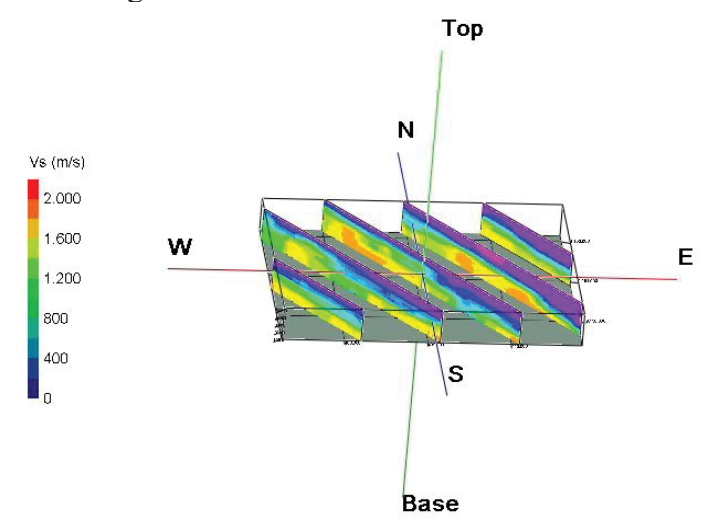

Fig. 6. Shear wave velocity values model in the study area.

The relationship between shear wave velocity and depth produces a value of Vs30. According to [21], the value of the shear wave velocity from the surface to a depth of 30 meters (Vs30) is used as a standard for amplification. The range of Vs30 values in the study area is $320-894 \mathrm{~m} / \mathrm{s}$. The resulting Vs30 value is then used for soil classification in the study area. Based on soil classification [22], the research area has 3 soil classifications, namely medium soil, very dense soil and soft rock and rock. The distribution of the shear wave velocity (Vs30) can be seen in Fig. 7.

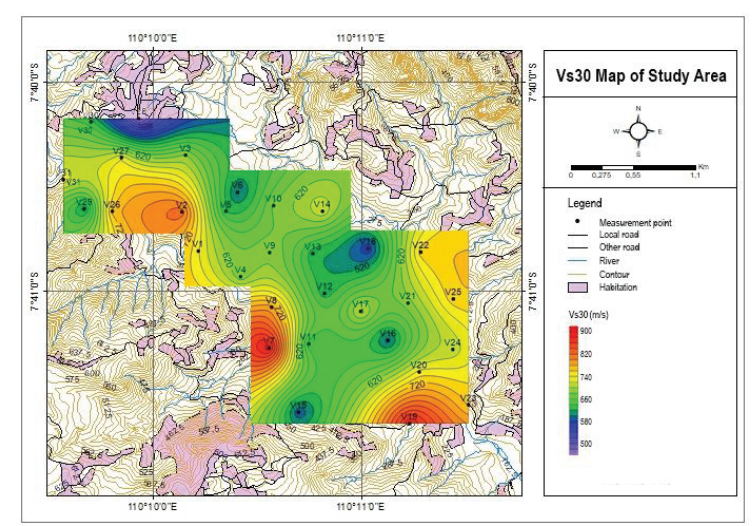

Fig 7. Map of the distribution of Vs 30 values in the study area.

Every soft rock has a small shear wave velocity value compared to hard rock because the shear wave velocity value is directly proportional to the density. A velocity wave will enlarge as it passes through a dense medium, so rocks that have a high density will require a high shear wave velocity when passing through the rock.

The density value has an inverse relationship with the porosity value. Porosity is the degree of cavities between the rock particles. If the rock has many cavities, the density of the rock is getting smaller. So that the rock with high porosity has a low density. 
Rocks with high porosity have a high risk of landslides because these rocks can absorb water easily. The small Vs30 value found on the main road in Samigaluh District indicates a high level of landslide susceptibility.

Based on the Vs value, the lithology in the study area consists of the first layer of topsoil, the second layer of clay, the third layer of soil, clay, breccia and pumice, and the fourth layer of bedrock in the form of andesite. To facilitate the visualization of lithology, an incision was made in the research area which was divided into 7 incisions based on the height and slope of the slopes and areas that have the potential for landslides. When it rains, areas that have thick sediment and are located at an altitude and steep slope will easily experience landslides. The trajectory map of the lithological incision of the study area can be seen in Fig. 8. and the lithological incision of the study area can be seen in Fig. 9.

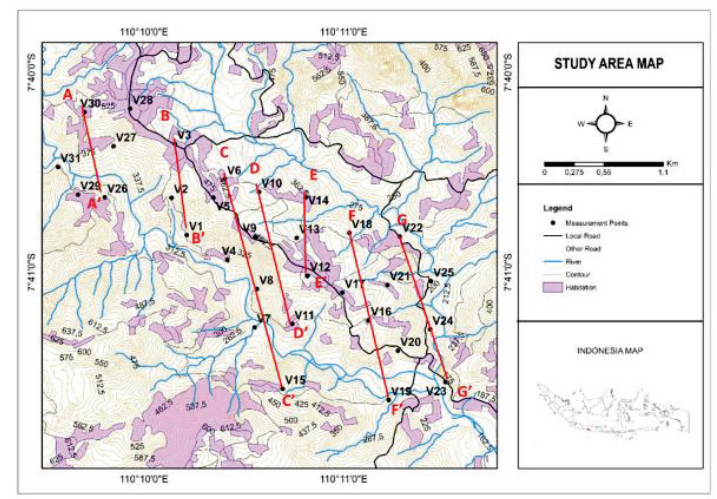

Fig. 8. Map of the trajectory lithological incision in the study area.

Many points in the research area such as V26, V2, V1, V6, V4, V8, V15, V10, V11, V14, V13, V16, V19, V24, V23 and several main roads are located on steep slopes that can occur landslides. In addition, there are several points located on steep slopes such as V30, V3, V9, and several main roads which of course can occur landslides on the edge of the main road.

The presence of andesite rock is a triggering factor for landslides because it is impermeable to water and can be used as a slip field for landslides. The type of soil that is clay, is the type of soil that easily passes water. In addition to clay, there are breccias and pumice which are capable of passing water in the subsurface layer of the study area.

With the nature of this type of soil, it makes the soil gain weight when it rains, so that if the soil is on an impermeable rock on a certain slope, the incoming water will be held back and the soil on a certain slope will have the potential to slide into a landslide.
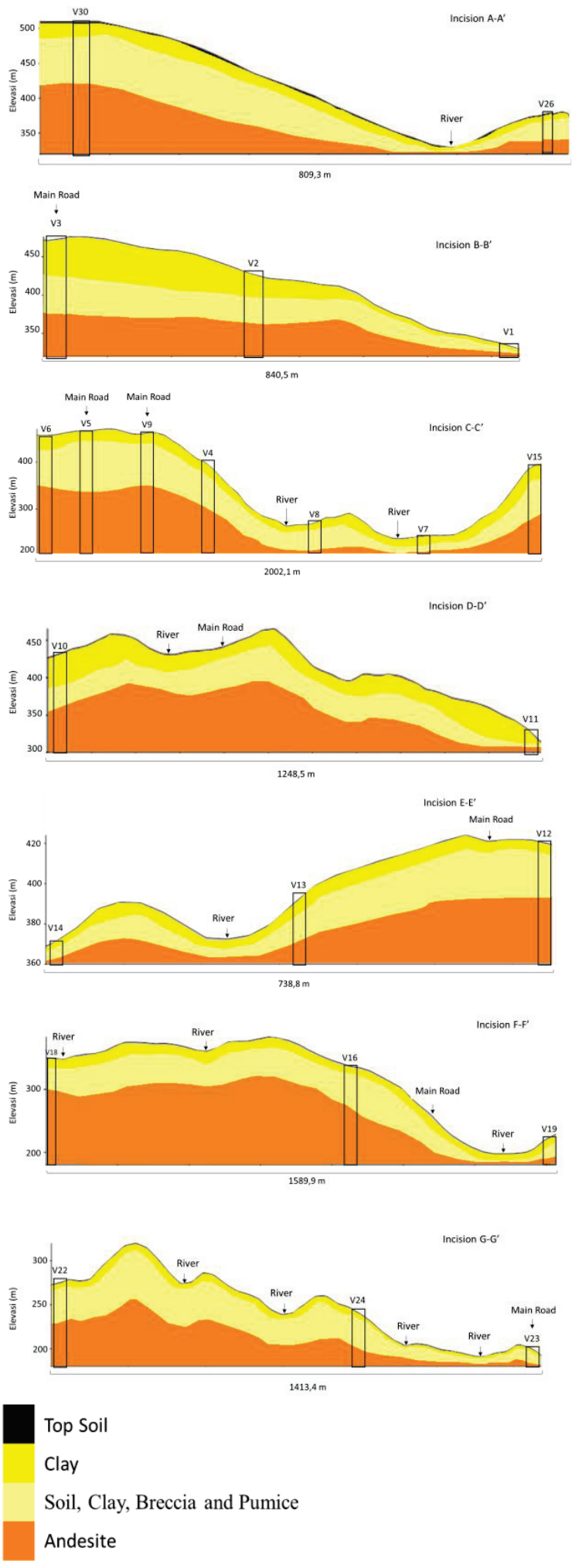

Top Soil

Clay

Soil, Clay, Breccia and Pumice

Andesite

Fig. 9. Lithological incision in the study area. 
The authors would like to thank BPBD Kulon Progo for the landslides data in this research area and the Geophysics Laboratory of FMIPA UGM for the research equipment.

\section{References}

1. D. M. Adfy et al., J. Fis. Unand 10, No.1, 8-14, (2021)

2. DEMNAS.URL:https.//tanahair.indonesia.go.id/de mnas/\#demnas

3. D. M. Cruden and D. J. Varnes, Spec. Rep. - Natl. Res. Counc. Transp. Res. Board 247, 36-75, (1996)

4. E. S. Nugroho, D. S. Hadmoko, C. Van Westen, and N. Kingma, Forum Geogr 26, No.2, 132-145, (2012)

5. Sutarmi, "Pemkab Kulon Progo Merintis Kawasan Pedesaan Agrowisata Menoreh Terpadu", (2020)

6. A. Syahputri and S. Sismanto, Jurnal Fisika Indonesia, 24(2): 66 (2020)

7. B. Ruwanto, Y. Sumardi, and D, Darmawan, Jurnal Penelitian Saintek 21(1): 66-74, (2016)

8. L. Katriani, D. Darmawan, B. Ruwanto, H. Lutfiana, and H. H. Prameswari, J. Phys. Conf. Ser. 1397, No.1, (2019)

9. H. Sulistiawan, S. Supriyadi, and I. Yulianti, Shear Wave Velocity Profiling Analysis for Site Classification Using Microtremor Single Station Method in AIP Conference Proceedings (2014)

10. F. J. Sánchez-Sesma, Earth, Planets and Space 69(1), (2017)

11. A. Gosar, Nat. Haz. Earth Syst. Sci 17(6): 925-937,
(2017)

12. F. E. S. Silalahi, Pamela, Y. Arifianti, and F. Hidayat, Geosci. Lett 6, No. 1, (2019)

13. M. Hobiger, Polarization of Surface Waves : Characterization, Inversion and Application to Seismic Hazard Assessment, (2011)

14. M. Hobiger, P. Y. Bard, C. Cornou, and N. Le Bihan, Geophys. Res. Lett 36, no. 14, pp. 1-5, (2009)

15. P. Y. Bard, K. Atakan, A. Anastasiadis, and R. M. Azzara, Guidelines for The Implementation of The H/V Spectral Ratio Technique on Ambient Vibrations-Measurements, Processing and Interpretations (SESAME Site Eff. Assess. using Ambient Excit, 2004)

16. Geospasial untuk Negeri, (2020)

17. P. Susilanto, D. Ngadmanto, B. Sunardi, and S. Rohadi, J. Lingkungan dan Bencana Geology 10, No. 2, 41-50, (2019)

18. A. R. Maulana, F. Y. Arwa, N. B. Wibowo, Purwanta, and S. Kiswanti, Analisis Kg dan Pga Berdasarkan Model Vs30 USGS di Kabupaten Kulon Progo (2019)

19. N. Budi, I. Huda, Buletin Meteoroogi Klimatologi dan Geofisika 1, No.2, 21-31 (2020)

20. A. I. Kanli, P. Tildy, Z. Prónay, A. Pinar, and L. Hermann, Geophys. J. Int 165, No. 1, 223-235, (2006)

21. BSN, Tata Cara Perencanaan Ketahanan Gempa untuk Struktur Bangunan Gedung dan Nongedung (Badan Standardisasi Indonesia , Bandung, 2012) 